\title{
A legislação brasileira de combate e prevenção do terrorismo quatorze anos após 11 de Setembro: limites, falhas e reflexões para o futuro
}

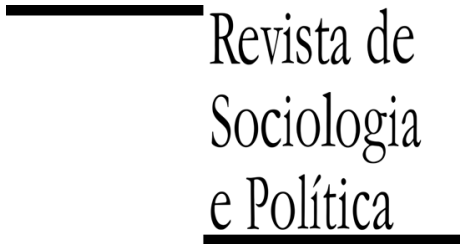

DOI 10.1590/1678-987315235304

\author{
Jorge Mascarenhas Lasmar
}

\section{Resumo}

O presente artigo diagnostica e analisa o desenho institucional e jurídico brasileiro na prevenção e combate ao terrorismo internacional bem como busca entender suas limitações. Para isso, foram utilizadas entrevistas com membros do governo brasileiro, incluindo as polícias Militar e Federal, bem como a pesquisa primária em documentos desclassificados e de fonte aberta além da legislação relevante. Concentrando-se no terrorismo internacional pós 11 de Setembro, observamos que o problema do terrorismo internacional também ocorre em território brasileiro. Em seguida, foi mapeada a estrutura e desenho do atual aparato de prevenção e combate ao terrorismo internacional existente no Brasil e identificadas suas limitações. Em sequência, foram analisadas as sérias deficiências do atual sistema normativo brasileiro de combate ao terrorismo. Tendo traçado o desenho da estrutura legal e institucional existente sobre o assunto, verificou-se que as atuais propostas de legislação em debate no Congresso Nacional não responde às necessidades reais desse problema. Essas falhas refletem a falta de uma estratégia e legislação específica de combate e prevenção do terrorismo no Brasil. Por isso, é essencial que se discuta a criação de uma legislação compreensiva dentro do marco da justiça criminal e assentado nos princípios básicos do Direito e da democracia, e em consonância com os direitos humanos e humanitário. Esses princípios e ramos do Direito estão preparados para lidar com esses casos complexos e não podem, de forma alguma, ser vistos como uma barreira ao combate ao terrorismo.

PALAVRAS-CHAVE: Brasil; terrorismo; violência política; contraterrorismo; legislação.

Recebido em 7 de Setembro de 2014. Aprovado em 15 de Outubro de 2014.

\section{Introdução ${ }^{1}$}

${ }_{1}$ Agradeço os pareceristas anônimos da Revista de Sociologia e Política por seus comentários.
Uma rápida busca pelos noticiários internacionais demonstra que a temática do terrorismo e violência política continua relevante e não resolvida 14 anos após o 11 de Setembro. Entre as notícias recentes de países assolados por esse problema encontramos a fragmentação da Líbia; as ações cada vez mais audazes do Boko Haram na Nigéria; o agravamento dos conflitos no Iêmen; a expansão do Estado Islâmico na Síria e Iraque; as incertezas no Afeganistão e Indonésia; a criação da $\mathrm{Al}$ Qaeda para o Subcontinente Indiano, e a lista poderia continuar.

Contudo, mesmo diante do grande volume de notícias, essa ainda nos parece uma realidade distante, longínqua e mesmo exótica. O discurso do Brasil como detentor de uma cultura pacifista e aberta somado às fortes negativas do governo acabam por criar a ilusão de que estamos livres e imunes dessa ameaça. Porém, diante da atual realidade do terrorismo internacional, nada poderia ser mais longe da verdade. O Brasil se encontra vulnerável ao terrorismo internacional assim como qualquer outro país. Dessa forma, é absolutamente necessário diagnosticar e analisar tanto o presente desenho institucional e jurídico brasileiro da prevenção e combate ao terrorismo internacional quanto suas limitações. Sua compreensão e o correto entendimento de nossas vulnerabilidades são essenciais para o futuro da segurança no Brasil. 
Para isso, concentrando-nos no terrorismo internacional ${ }^{2}$ após o 11 de Setembro, descreveremos na Seção II o contexto do terrorismo internacional no Brasil. Na seção III, mapearemos a estrutura e desenho do atual aparato de prevenção e combate ao terrorismo internacional existente no Brasil para, na seção IV, analisarmos os limites do sistema normativo brasileiro de combate ao terrorismo. Tendo traçado o desenho da estrutura legal e institucional existente sobre o assunto, abordaremos os limites das atuais propostas de legislação em debate no Congresso (seção V) e, finalmente, faremos uma breve discussão dos possíveis impactos do contexto internacional do terrorismo para o Brasil (seção VI).

\section{O contexto do terrorismo internacional no Brasil}

Em realidade, o Brasil não é um país frequentemente associado às discussões acerca do terrorismo ou contraterrorismo. Não obstante grande parte da esparsa literatura existente sobre o assunto se referir aos movimentos de guerrilha de esquerda durante as décadas de 1960 e 1970, o atual caso brasileiro é um interessante, mas pouco explorado, objeto de pesquisa para os estudos de terrorismo e violência política. A combinação de um forte desejo de criminalizar o terrorismo combinado com a presença de ex-participantes de movimentos de esquerda que se utilizaram da violência política no governo, adicionados a uma pesada estrutura jurídica e burocrática, uma grande fragilidade institucional, além da persistência de movimentos sociais e sérias questões ligadas ao crime organizado - para não mencionar sua posição como acolhedor de grandes eventos como as Olimpíadas - justificam o caso de uma investigação mais detalhada sobre o terrorismo e contraterrorismo no Brasil.

\section{II.1. O Brasil é atualmente ameaçado por algum grupo terrorista internacional?}

${ }^{2}$ Não cabe aqui, realizar a importante mas complexa discussão acerca da definição do que é terrorismo. Assim adotaremos a definição de Diniz: terrorismo é o "emprego do terror contra um determinado público, cuja meta é induzir (e não compelir nem dissuadir) num outro público (que pode, mas não precisa, coincidir com o primeiro) um determinado comportamento cujo resultado esperado é alterar a relação de forças em favor do ator que emprega o terrorismo, permitindo-lhe no futuro alcançar seu objetivo político qualquer que esse seja" (Diniz 2004, p. 28).
A resposta curta é: não. O Brasil é um país orgulhoso do pacifismo de sua política externa e, embora enfrente internamente alguns problemas sérios relacionados ao crime organizado, não foi palco de nenhum ataque terrorista de destaque nos últimos 30 anos. De fato, até 2011, o Brasil se encontrava no nível mais baixo do Índice Global de Terrorismo (IEP 2012, p. 5) e, apesar de o índice de 2014 registrar alguns casos, o Brasil ainda se situa no nível mais baixo de impacto do terrorismo (IEP 2014).

Todavia, a resposta longa não é tão simples. É fato que o Brasil se encontra, até o momento, livre de ataques terroristas feitos por grupos internacionais. Não obstante, isso não quer dizer que estejamos livres da presença de indivíduos ligados a grupos terroristas internacionais e muito menos que estejamos isentos da possibilidade de nos tornar vítimas de ataques futuros. Não podemos nos esquecer que a atividade terrorista não se encerra apenas nos atentados terroristas em si. Ao contrário do que acredita o senso comum, a atividade terrorista vai muito além do atentado. De fato, apesar de toda a atenção da mídia e nossa curiosidade, o que chamamos de "ataque terrorista" é apenas uma pequena fase dentro do que podemos chamar de ciclo da atividades terrorista (Don et al., 2007 , p. 3). Em realidade, qualquer ataque é precedido por uma série de atividades interconectadas como recrutamento, radicalização e difusão de ideias, financiamento, treinamento, logística, administração de recursos materiais, compartilhamento de conhecimento e materiais, planejamento, vigilância etc. Da mesma forma, após o ataque, o grupo terrorista ainda se engaja em outras atividades como fuga e evasão dos terroristas sobreviventes, difusão e propaganda dos fatos e ideologias radicais do grupo/indivíduo, exploração política e ideológica dos atentados etc. 
${ }^{3}$ Por exemplo, o governo brasileiro frequentemente nega afirmativas de oficiais estadunidenses relacionadas à presença de atividades ligadas ao terrorismo na Tríplice Fronteira exigindo a apresentação de provas (American Embassy in Brasilia 2008, p. 2).
A importância em se entender que os atentados terroristas são frutos de uma longa cadeia de ações racionais planejadas e interconectadas reside no fato de que grande parte dos argumentos sobre a inexistência do problema do terrorismo internacional no Brasil se baseia no histórico recente da inexistência de ataques terroristas em território brasileiro. Essa imagem é ainda mais reforçada por dois outros fatores. Em primeiro lugar, grande parte do governo brasileiro adota uma postura de "negacionismo" que não apenas insistentemente nega publicamente a existência de qualquer atividade terrorista internacional em solo pátrio, mas também reage fortemente contra qualquer alegação em sentido contrário $^{3}$ (American Embassy in Brasilia 2008, p. 1). Em segundo lugar, o "crime de terrorismo" continua sem ser tipificado no Brasil. Dessa forma, casos relacionados ao terrorismo acabam sendo investigados sob a guisa de outros crimes ou infrações tanto penais quanto administrativas tais como falsificação de documentos, divulgação de propaganda racista, entrada ilegal no país etc., o que dificulta a identificação clara desses casos como atividades terroristas.

Entretanto, apesar das frequentes negativas das autoridades brasileiras e da falta de foco na mídia sobre as atividades terroristas que não o ataque, há crescente evidência documental de que uma série de atividades ligadas ao apoio e facilitação ao terrorismo no estrangeiro de fato aconteceram e continuam a acontecer dentro do território brasileiro. Nesse sentido, uma análise cuidadosa de diversos documentos encontrados em fontes abertas é reveladora. Hoje é público que não somente a Polícia Federal estadunidense (FBI) em diversas ocasiões alertou (e tem alertado) o governo brasileiro sobre a ocorrência dessas atividades em território brasileiro (American Embassy in Brasilia 2008; 2009a; 2009b; United States 2014), como também documentos oficiais do governo estadunidense afirmam a cooperação operacional com a Polícia Federal Brasileira na apreensão e monitoramento de indivíduos ligados a grupos terroristas internacionais, no fornecimento de evidência e provas relacionadas a suspeitos de terrorismo além do fornecimento de treinamento e atuação em operações conjuntas (United States 2014, p. 208). Da mesma forma, uma apreciação atenta de várias investigações da Polícia Federal brasileira e depoimentos de autoridades evidenciam a existência de atividades ligadas ao terrorismo internacional em território brasileiro.

Em realidade, o terrorismo internacional tem sido uma preocupação da Polícia Federal desde o início da década de 1980. Os atentados à embaixada e quartéis estadunidenses em Beirute, em 1983, suscitou a preocupação no governo brasileiro de que sequestros de aeronaves e atentados a bomba pudessem vir a ocorrer no Brasil. Essa preocupação foi real o suficiente para levar a que uma Comissão Parlamentar Mista de Inquérito recomendasse ao Ministério da Justiça a criação de um grupo especializado em contraterrorismo. Esse grupo começou a operar alguns anos mais tarde se tornando o Comando de Operações Táticas (COT) da Polícia Federal. O COT se encontra ativo até os dias de hoje e ainda tem como uma de suas competências a resposta cinética a atos de terrorismo.

De maneira mais concreta, podemos (re)traçar a passagens pelo Brasil de indivíduos iranianos ligados à exportação de ideologia radical durante as décadas de 1980 e 1990. Sabe-se hoje, por exemplo, que em maio de 1984, Moshen Rabbani (frequentemente considerado como o mentor de vários ataques terroristas) enviou ao Brasil o mullah iraniano Mohammad Tabataei Einaki. Segundo algumas fontes, o envio de Einaki foi uma consequência direta de um seminário ocorrido na República Islâmica do Irã em 1982 atendido por 380 religiosos de 70 países. Esse seminário foi considerado por alguns como um marco na mudança do método de expansão da Revolução Iraniana que se voltaria para um processo mais ativo de infiltração de uma visão mais radical e violenta do Islã fora do Irã (Nisman \& Burgos 2013b, p. 3). Sabe-se, com 
${ }^{4} \mathrm{O}$ termo se refere ao que é permitido aos Muçulmanos pelo direito Islâmico.
${ }^{5}$ O juiz Juan Jose Galeano sofreu um processo de impeachment durante $o$ processo. certeza, que Einaki entrou no Brasil inicialmente com um visto de 30 dias, que foi posteriormente estendido por mais 12 meses. Seu ingresso no Brasil se deu enquanto representante do governo iraniano encarregado de certificar que o

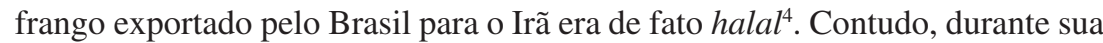
estada no Brasil, os embaixadores do Iraque e Arábia Saudita apresentaram acusações de que Einaki teria se engajado em atividades de radicalização e recrutamento para causas ligadas ao terrorismo iraniano em São Paulo, Rio de Janeiro e Curitiba (Nisman \& Burgos 2013a, p. 409). Diante das acusações, Einaki foi investigado pela Polícia Federal e acabou sendo expulso do Brasil pela suspeita de seu envolvimento com o grupo xiita libanês Hezbollah (Nisman \& Burgos 2013a, p. 409) mas sob a acusação formal de engajamento em atividades políticas diferentes das declaradas para sua entrada no país (Nisman \& Burgos 2013b, p. 9).

A passagem de Einaki e sua relação com Rabbani são ainda mais relevantes se também consideramos que as atividades preparatórias dos ataques terroristas à embaixada Israelense em Buenos Aires em 1992 e do atentado suicida na Associação Mútua Israel-Argentina (AMIA), em 1994, são frequentemente vinculadas ao Brasil (Levitt 2012; Nisman \& Burgos 2013a; OAG 2006). De fato, recentemente, o Procurador Especial Alberto Nisman divulgou os resultados de suas investigações sobre o caso AMIA chegando às mesmas conclusões do juiz original do caso ${ }^{5}$. Segundo Nisman, fortes evidências circunstanciais apontam para o Governo do Irã e alguns de seus diplomatas locais como planejadores e financiadores do atentado. Seu relatório aponta ainda a participação do Hezbollah como apoiador operacional desse atentado que matou 85 e feriu mais de 300 pessoas. Entre os agentes iranianos ligados ao atentado, Moshen Rabbani, que também é acusado nos Estados Unidos de ter ajudado a planejar o ataque malsucedido aos tanques de combustível do aeroporto JFK em Nova York, foi identificado como o autor intelectual dos ataques. A investigação de Nismam aponta para várias conexões entre Rabbani e o Brasil. Segundo o Procurador Especial, relatórios de inteligência comprovam que em 2 de agosto de 1994 Rabbani encontrou com o brasileiro Ghazi Iskhandar cuja ligação com o grupo Hezbollah foi estabelecida quando seu nome foi encontrado em uma agenda de compromissos do membro do Hezbollah, Bassem Harakeh, no momento em que esse foi preso na Noruega por sua ligação com atividades terroristas (Nisman \& Burgos 2013a, p. 428). Da mesma forma, a imprensa brasileira levantou suspeitas de que o brasileiro Rodrigo Jalloul tenha atuado como o braço direito de Rabbani para suas atividades clandestinas no Brasil (Farah 2012, p. 20).

De maneira mais concreta, o relatório relembra a aliança estratégica entre a República do Irã e o grupo Hezbollah e aponta para os fortes laços que o grupo possui na Tríplice Fronteira e em outras cidades brasileiras como São Paulo e Curitiba. As investigações de Nismam revelam que o coordenador das operações terroristas na Argentina agiu a partir de Foz do Iguaçu fazendo uso de um telefone atribuído a um certo Andre Marques (Nisman \& Burgos 2013b, p. 9). Esse mesmo número de telefone foi conectado a várias ligações telefônicas feitas pelo grupo operacional do atentado (Nisman \& Burgos 2013a, p. 25 e p. 565). O relatório aponta ainda que o attaché Civil da Embaixada do Iran em Brasília entre 1991 e 1993, o Sr. Jaffar Saadat Ahmad-Nia, era um agente da inteligência iraniana (VEVAK). Segundo depoimentos constantes do relatório, o Sr. Jaffar teria ido à Argentina para ajudar a resolver potenciais problemas logísticos do grupo operacional dos atentados. De qualquer forma, independentemente da acusação, os registros demonstram que o Sr. Jaffar entrou na Argentina no dia 18 de março de 1992 (dia anterior aos ataques) e retornou no dia 18 de março do mesmo ano (isso é, no dia posterior ao ataque à embaixada Israelense em Buenos Aires) (Nisman \& Burgos 2013b, p. 27). 
${ }^{6}$ Ver, por exemplo, Fields (2002).

7 Uma exceção importante é a questão do ópio no Afeganistão.
Esse não é um fato isolado. Os documentos da investigação do caso AMIA, apontam ainda para a ocorrência de outras atividades extremistas em território brasileiro. Nismam revela que relatórios da Polícia Federal brasileira informam a presença de membros de grupos como Hezbollah, Hamas, Jihad Islâmica e Gamat Al-Islamiyah nos estados de São Paulo, Paraná e Distrito Federal. O documento cita ainda que, de acordo com a Interpol em Brasília, frequentemente membros do Hezbollah se reuniram em São Paulo (ibidem) e usaram passaportes brasileiros falsos em suas atividades de financiamento desse grupo (Nisman \& Burgos 2013a, p. 558). Da mesma forma, é sabido, por exemplo, que tanto a Agência Brasileira de Inteligência (ABIN) quanto a Polícia Federal acompanharam em 1995 a presença do Khalid Sheikh Mohammed no Brasil. Atualmente preso em Guantánamo, Sheikh Mohammed ficou conhecido como a mente por trás dos ataques de 11 de Setembro e esteve ligado a vários ataques da Al Qaeda entre 1993 e 2003. Entre os atentados terroristas em que foi implicado incluem-se os planos de assassinar o Papa João Paulo Segundo durante sua visita a Manila, o famoso plano Bojinka que planejou a explosão quase simultânea de 12 voos comerciais com destino aos EUA, a tentativa de Richard Reid de explodir um sapato bomba e os atentados de Bali em 2002, entre outros. De acordo com o famoso 9/11 Commission Report, Mohammed esteve em Foz do Iguaçu em 1995 para encontrar com um contato indicado por Mohamed Atef (Abu Hafs), à época chefe operacional da Al Qaeda (9/11-Commission 2005, p. 148).

Combinados com a percepção (nem sempre real) de que a Tríplice Fronteira possui uma baixa presença do Estado, apresenta um ambiente de segurança relaxada e é a sede de uma série de atividades e organizações criminosas, esses relatos vieram a reforçar um certo mito de que a região se tornou um paraíso para grupos e indivíduos terroristas no Brasil $l^{6}$. Contudo, na realidade, o status da Tríplice Fronteira como capital nacional do terrorismo é questionável. No que diz respeito à criminalidade local, operações recentes da polícia brasileira têm aumentado a segurança da região e, em especial, na Ponte da Amizade. Operações policiais no local também resultaram na criação de uma unidade de polícia marítima especial, a criação de uma unidade de operações de fronteira independente e no empenho de utilização de veículos aéreos não-tripulados (VANTS) na região. O resultado, tem sido a migração de atividades criminais para outras áreas de fronteira ao longo do Rio Paraná e Lago Itaipu aproveitando-se das fronteiras porosas da região (United States 2010, p. 152). Ademais, a relação do terrorismo com o crime organizado sempre foi conflituosa e menos direta do que muitos pressupõem, especialmente no que diz respeito ao narcotráfico. Os grupos terroristas têm receio em se vincularem a grupos narcotraficantes já que, além de psicotrópicos, estupefacientes e afins serem considerados contrários à religião islâmica $(\text { haram })^{7}$, grupos narcotraficantes acabam recebendo muita atenção dos serviços de inteligência e policiais governamentais, o que os grupos terroristas querem evitar. De maneira semelhante, enquanto os grupos terroristas de um modo geral lutam contra o Estado, os grupos de crime organizado querem ter o mínimo possível de fricção com o Estado, por exemplo, através do suborno de autoridades e agentes policiais, fiscalizadores etc. (USNCoTAuUS 2005, p. 4).

Assim, embora a Tríplice Fronteira seja a região alvo da maioria das pesquisas acadêmicas sobre o assunto, a evidência empírica aponta para um problema que vai muito além da região. Entre exemplos de ações da Polícia Federal ligadas à questão do terrorismo internacional no Brasil, fora da Tríplice Fronteira, podemos citar a Operação Panorama que teve lugar no Paraná e Mato Grosso em 2005. Na ocasião, foram emitidos 28 mandatos de prisão e 19 extremistas liderados pelo libanês Jihad Chaim Baalbaki e pelo jordaniano Sael Basheer Yhaya Najib Atari foram presos: nove em Foz do Iguaçu, quatro em 
Curitiba, quatro em Paranaguá, um em Matinhos e um em Cuiabá. Mais uma vez, a falta de legislação específica levou a que os detidos fossem acusados de outros crimes e contravenções tais como: obtenção fraudulenta de vistos de permanência para estrangeiros; falsificação de passagens aéreas; clonagem de cartões de créditos; clonagem de telefones celulares e utilização fraudulenta de chips de telefonia móvel; contrabando e descaminho; falsificação de passaportes e outros documentos; crimes de moedas falsas; central clandestina de telefonia; comércio clandestino de armas de fogo; tráfico ilícito de substâncias entorpecentes; clonagem de veículos; formação de quadrilha ou bando. Em outro exemplo, em 2007, a Polícia Federal prendeu um sunita extremista que praticava atos de apoio ao terrorismo em Santa Catarina. Sua prisão se deu com base em sua falha na declaração de entrada de bens no Brasil o que permitiu sua deportação.

Esses exemplos demonstram que a presença no Brasil de indivíduos ligados a grupos extremistas que se utilizam da violência política e terrorismo tais como Al Qaeda, Hezbollah e Gammaa al-Islamiya têm sido constantemente reportadas e investigadas. A evidência mais forte disto é o depoimento do Sr. Daniel Lorenz, na época Chefe da Divisão de Inteligência da Polícia Federal. O Sr. Lorenz confirmou em uma audiência pública em 7 de julho de 2009 (Brasil 2009) que o Sr. Khaled Hussein Ali, um indivíduo preso em março daquele ano por crimes de racismo em São Paulo, tinha conexões com a Al Qaeda e era um dos líderes globais da Jihad Media Battalion (JMB), um dos braços de divulgação e recrutamento da rede $\mathrm{Al}$ Qaeda. A importância desse fato é digno de nota. É importante destacar que tanto o recrutamento quanto a difusão de uma ideologia radical são centrais para a continuidade do terrorismo e, em parte, explicam a falha da Guerra Global Contra o Terror estadunidense. Enquanto a ideologia radical existir e seu poder de atração não for combatido, o terrorismo permanecerá com um alcance e apelo transnacional criando não apenas terroristas profissionais, mas também os chamados lobos solitários e terroristas domésticos.

É exatamente nesse sentido que o Sr. Ali teria usado sua lan house em São Paulo para coordenar atividades do JMB. Entre estas atividades, destacam-se a propaganda para a $\mathrm{Al}$ Qaeda, o fornecimento de espaço virtual para recrutamento, apoio, treinamento, comunicações além de suporte a operações de segurança para atos de terrorismo praticados no exterior. Segundo relatos da mídia, a investigação da Polícia Federal teria começado através do fornecimento de um endereço de IP repassado pelo FBI ao governo brasileiro (Coutinho 2011). Segundo Coutinho (idem), a prisão do Sr. Ali foi feita em um momento em que esse acessava seus arquivos de modo a permitir a leitura do material encriptado pelo sistema Mujahideen Secrets. Entre o material encontrado em seu computador, além de manuais de táticas terroristas, foram localizados e-mails solicitando o bloqueio do acesso de alguns indivíduos presos em Gaza pelo governo israelense para que esses não tivessem mais acesso ao banco de dados do JMB (idem, p. 91). A análise desse material comprovou o envolvimento do Sr. Ali em atividades de propaganda, apoio logístico, recrutamento e apoio à rede Al Qaeda. De posse desse material, o Sr. Ali foi acusado pela Polícia Federal de crimes de racismo e antissemitismo. Contudo, foi liberado 21 dias após ser preso demonstrando alguns dos problemas práticos da inexistência de um aparato legal para tratar dessa questão (mais sobre isso abaixo). Ademais, fiel à postura do governo brasileiro de negar a existência de qualquer atividade terrorista em nosso território, o promotor responsável pelo caso emitiu declarações negando os relatos da mídia que afirmavam o envolvimento do Sr. Ali com o terrorismo (American Embassy in Brasilia 2009b, p. 2).

Ainda de acordo com as investigações da Polícia Federal, a maioria dos casos envolvendo suspeitos de atividades ligadas ao terrorismo têm acontecido 
em São Paulo ou outras cidades como Curitiba e Foz do Iguaçu (American Embassy in Brasilia 2008, pp. 2-3). Essas investigações incluem casos relacionados ao financiamento do terrorismo, recrutamento e redes de falsificação de documentos. Um exemplo dessas investigações é o caso do libanês Kamed El Laouz que também atuava como um dos coordenadores da Jihad Media Battalion e foi preso pela Polícia Federal em São Paulo em março de 2009 (Coutinho, 2011). Outro exemplo acontecido em São Paulo é o caso do egípcio Hesham Ahmed Marhmoud Eltrabily que foi condenado por um ato terrorista que culminou no assassinato de 62 turistas em Luxor, Egito, mas, apesar de ter sido detido em São Paulo, teve seu pedido de extradição negado (idem).

Ainda de acordo com o testemunho do Sr. Lorenz (Brasil 2009), a Polícia Federal tem identificado uma crescente evolução da ameaça terrorista no Brasil. Após investigações iniciais, a percepção inicial da Polícia Federal de que os terroristas estavam meramente utilizando o território brasileiro em trânsito ou para se esconderem deu lugar a novas evidências de que alguns indivíduos com ligações com grupos terroristas estavam em realidade ativamente buscando estabelecer residência permanente no Brasil através de casamentos ou adotando crianças brasileiras. Investigações posteriores identificaram alguns brasileiros que foram atraídos pela ideologia extremista e pela ideia do martírio; alguns chegaram a viajar para o Irã e Oriente Médio no que a Polícia Federal acredita ser uma busca por instrução religiosa radical. Finalmente, evidência tem surgido de que alguns desses indivíduos estão ativamente apoiando e financiando grupos terroristas fora do Brasil, através de ajuda com recrutamento, financiamento, treinamento, logística e reconhecimento (idem).

É importante relembrarmos, ainda, que o terrorismo religioso não é a única possibilidade de ocorrência de atividade terrorista no Brasil. Existem, por exemplo, registros de casos de crimes raciais violentos em estados como São Paulo, Paraná e Rio Grande do Sul por indivíduos e grupos como Carecas do Subúrbio, Carecas do ABC e White Power que podem estar relacionados ao uso de material com conteúdo terrorista. Da mesma forma, a adoção de táticas e técnicas terroristas por grupos narcotraficantes tem sido outra preocupação das autoridades. Lembramos ainda que as longas e porosas fronteiras brasileiras, somadas a uma capacidade de vigilância e controle insuficientes, podem levar à infiltrações de grupos que se utilizam da violência política, tais como as FARCS em território nacional.

\section{O atual aparato de prevenção e combate ao terrorismo internacional no Brasil}

No Brasil, não existe uma única instituição centralizada e específica encarregada de prevenir e combater o terrorismo internacional. Em realidade, há uma verdadeira justaposição de competências parciais e difusas sobre essa matéria. Diversas agências de segurança e inteligência brasileiras atuam na prevenção e combate ao terrorismo internacional. O monitoramento ativo e prevenção das ameaças são feitos pela ABIN e Interpol com a contribuição de "adidâncias", agências de inteligência estrangeiras ou outros órgãos internacionais. Sabe-se que esses órgãos e agências internacionais têm frequentemente repassado inteligência e atuado tanto no treinamento quanto agido em cooperação operacional com a Polícia Federal brasileira (American Embassy in Brasilia 2008, p. 1). Informado por esses órgãos de inteligência ou movido por inteligência própria, a Polícia Federal tem exercido a repreensão policial através da vigilância e investigação de indivíduos possivelmente ligados a movimentos extremistas, financiamento de terrorismo, redes de falsificação de documentos e outras atividades de facilitação e apoio ao terrorismo. Segundo Jacini, essas atividades visam "prevenir, obstruir, identificar e neutralizar condutas terroristas" (Jacini 2002, p. 76). 
A Polícia Federal também atua na prevenção e obstrução de possíveis atividades terroristas em solo brasileiro através do monitoramento e vigilância dos pontos de fronteira e imigração brasileira. Essa atividade conta com a coleta e consulta de informações ligadas aos sistema nacional de procurados e impedidos (SINPI), ao projeto Sentinela, que fiscaliza o tráfego internacional, além da base de dados da Interpol. Assim, a competência e atuação da Polícia Federal no combate ao terrorismo internacional em solo brasileiro se encontra dividida pela atuação de seus diversos órgãos internos como a Diretoria de Polícia Judiciária, a Divisão Antiterrorismo a Coordenação Geral de Polícia Marítima, Aeroportuária e de Fronteiras, a Coordenação Geral de Ordem Pública e Social (a quem compete as investigações e inquéritos policiais de crimes por ato de terrorismo), a Coordenação Geral de Combate ao Crime Organizado e Inquéritos Especiais e a Coordenação Geral do Comando de Operações Táticas (idem, p. 75).

No que diz respeito à resposta cinética a atentados terroristas, há uma complexa divisão de competências. No caso das ações de repressão policial há uma divisão de competências entre as polícias Federal, Militar e Civil. No caso da Polícia Federal a resposta tática fica a cargo da Divisão Antiterrorismo (DAT) e do Comando de Operações Táticas que atua especialmente em ações táticas como empoderamento ilícito de aeronaves e resposta tática ao terrorismo. Já no caso da Polícia Militar, de cunho estadual, sua atuação na resposta a ataques terroristas é feita através de seus batalhões de operações especiais tais como o BOPE e o GATE. A Polícia Civil, também de cunho estadual, atua na resposta policial a eventos terroristas também através de suas divisões de operações especiais tais como o DOE. Já as medidas militares de caráter repressivo em resposta ao terrorismo estão à cargo do Comando do Exército/Ministério da Defesa através de sua Brigada de Operações Especiais (BOE) e, no caso de ciberterrorismo, do seu Centro de Defesa Cibernética (CDCiber).

Outro importante fronte do combate ao terrorismo no Brasil digno de destaque se dá no plano financeiro. O Brasil, como membro da Financial Action Task Force (FATF), de sua divisão de Lavagem de Dinheiro para a América do Sul (GAFISUD) e dos grupos regionais em estilo FATF (FSRB), criou um grupo de trabalho dentro do Ministério da Justiça para incorporar as recomendações desses órgãos que incluem diversos dispositivos para combater o financiamento do terrorismo. Todavia, talvez o mais importante órgão envolvido no combate ao financiamento do terrorismo seja a Unidade de Inteligência Financeira (FIU) do Brasil, o Conselho de Controle de Atividades Financeiras (COAF). A COAF atua na detecção e combate ao financiamento ao terrorismo através de ações de inteligência financeira. A COAF também realiza a verificação para o congelamento de fundos ou bens ligados a terroristas ou organizações terroristas constantes na lista emitida pelo Conselho de Segurança da ONU consoante suas resoluções n. 1267 e 1373, muito embora não tenha encontrado nenhum bem relacionado a essa lista até o presente momento. Por fim, é importante ressaltarmos que apesar de o trabalho da COAF ser considerado muito efetivo, o Brasil ainda não criminalizou o financiamento do terrorismo conforme recomendação do último Mutual Evaluation Report: Anti-Money Laundering and Combating the Financing of Terrorism - Federative Republic of Brazil do FATF (mais sobre isso abaixo).

Apesar da atuação de todos esses órgãos do governo no combate e prevenção ao terrorismo internacional, na prática, percebe-se que na maioria dos casos os órgãos envolvidos possuem apenas uma competência residual em relação ao terrorismo internacional. Soma-se a isso uma crônica falta de recursos material, tecnológico, financeiro e humano (Souza 2009, p. 33), refletindo, na realidade, um problema estrutural muito maior. Conforme destaca Raza, a pura e simples integração de novas jurisdições e instituições ligadas à prevenção e combate do 
${ }^{8}$ Essa sigla se refere a elementos de comando e controle das atividades militares.

${ }^{9}$ Ver Rees e Aldrich (2005). terrorismo ao exército não pode ser vista como a resposta a um problema histórico de desempoderamento das forças armadas, mas é preciso um novo desenho e reformulação de sua doutrina e C4IC ${ }^{8}$ (Raza 2005, p. 6). O mesmo pode ser dito das outras agências governamentais envolvidas. O grande problema do atual desenho institucional é que este ecoa a falta de uma estratégia nacional de combate ao terrorismo articulada e consolidada. Essa lacuna transparece na ausência de um aparato institucional e legal, na escassez de cooperação interagências e na insuficiência de sinergia interinstitucionais agravadas por disputas de competência e por recursos. Novamente, esse não é um problema trivial. A articulação e redistribuição das competências, redesenho institucional e forte esforço na integração de agências relacionadas à prevenção e combate do terrorismo foi uma das principais prioridades no modelo de reforma de segurança doméstica estadunidense após 11 de Setembro (9/11-Commission 2005). E, mais importante, a falta de uma estratégia e legislação definidas são importantes pré-condições em qualquer redesenho do modelo de anti e contraterrorismo, já que o marco estratégico e jurídico determinarão, pelo menos em um Estado democrático de direito, a definição do seu modelo (policial vs. militar vs. epidemia) $)^{9}$.

\section{O sistema normativo brasileiro de combate ao terrorismo}

Para entendermos o porquê do atual desenho institucional do sistema normativo brasileiro de combate ao terrorismo (ou sua falta), é essencial compreendermos a postura negacionista do governo brasileiro. Os exemplos citados anteriormente, longe de serem exaustivos, ilustram tanto a realidade da presença de atividades ligadas ao terrorismo internacional em território brasileiro quanto a consciência das autoridades brasileiras acerca desse assunto. Por isso, podemos perguntar o que tem justificado a forte postura do governo brasileiro de publicamente negar a existência de atividades ligadas ao terrorismo no Brasil diante de tantas evidências? Na realidade, são vários os argumentos que justificam essa posição. Um dos argumentos frequentes se baseia no medo de que qualquer tratamento da questão do terrorismo venha a estigmatizar a população muçulmana brasileira. Outro argumento constantemente aventado alega que o reconhecimento da existência de atividades terroristas em território brasileiro pode vir a afetar o turismo internacional no Brasil. Outras autoridades chegam mesmo a alegar que a existência de um corpo normativo de combate ao terrorismo ou o reconhecimento de sua existência levariam a uma construção de uma imagem de alinhamento brasileiro com a política externa estadunidense da Guerra Global Contra o Terror (American Embassy in Brasilia 2008, p. 2). Esse alinhamento, por sua vez, poderia ser visto como uma política externa e interna provocativa que poderia atrair problemas políticos e de segurança para o Brasil (American Embassy in Brasilia 2009b). Souza (2009, p. 32) aponta ainda que existe uma percepção entre alguns políticos de que o Brasil é um país pacífico e tolerante o que, de alguma forma, torná-lo-ia imune ao terrorismo. Um outro importante argumento aventa o medo de que a criação de um corpo normativo sobre o assunto venha a atrair o terrorismo para o Brasil. O Deputado Federal Raul Jungmann, por exemplo, alegou em uma audiência pública que um assessor do Ministro da Justiça Tarso Genro teria alegado que a aprovação de uma legislação antiterrorista atraria o terrorismo para o Brasil (Brasil 2009, p. 16). Por fim, não podemos deixar de mencionar que vários políticos da alta cúpula governamental estiveram envolvidos em atividades ou grupos que se utilizaram da violência política durante a ditadura militar brasileira a fim de combatê-la, chegando mesmo a serem perseguidos e, em alguns casos torturados.

É compreensível, portanto, o receio brasileiro em se adotar uma legislação sobre o assunto, bem como o temor de que grupos de movimentos sociais legítimos venham a ser taxados de grupos terroristas. Também não podemos 
${ }^{10}$ Sobre esse assunto, ver Donohue (2008).

${ }^{11}$ Se bem que a lei autoriza a utilização de conhecimento obtido em investigação corrente que contenha informações sobre crimes futuros. nos esquecer que esse é um assunto espinhoso que leva ao limite a tensa e tênue divisória existente entre o dever do Estado de proteger seus cidadãos e seu dever de garantir os direitos e garantias fundamentais de seus indivíduos. Não há dúvidas de que qualquer legislação de prevenção e combate ao terrorismo é complexa, possui um alto custo social e institucional de implementação e, certamente, levantará oposição ${ }^{10}$.

Contudo, independentemente de concordarmos ou não com os argumentos apresentados, a inexistência de um aparato legal específico também traz sérios problemas. A princípio, pode-se argumentar que esse silêncio não é problemático. Afinal, domesticamente, qualquer ataque terrorista recairá sobre um ou mais crimes já existentes em nosso direito penal. É difícil imaginar um ataque terrorista que não possa ser enquadrado em tipos penais tais como assassinato, lesão corporal, destruição de bens públicos, incêndio criminoso, sequestro etc. Não obstante, conforme discutido acima, a atividade terrorista não consiste apenas nos atentados. E mais, conforme discutiremos abaixo, os grupos e indivíduos ligados ao terrorismo internacional possuem características e um modus operandi que o distinguem de práticas criminais comuns e trazem sérios desafios ao Direito Penal existente. Apesar de entendermos que não é necessária a substituição ou abandono do Direito Penal para lidar com esses casos, é absolutamente necessário repensar alguns de seus institutos à luz de uma legislação específica para esse seja capaz de lidar com esse fenômeno de maneira eficiente.

A implementação de políticas e ações eficazes de prevenção e combate ao terrorismo também torna necessário que se repense a atual prática de alguns institutos do Direito Penal como: o uso de informantes criminosos e cúmplices; delação premiada; imunidade e leniência; proteção à testemunha; obstrução da justiça diante da intimidação de testemunhas, oficiais ou comunidades vulneráveis; investigações transfronteiriças; independência de promotores; facilitação do uso de equipamento técnico e de interceptação; desburocratização de investigações conjuntas; interrogatórios à distância (por vídeo ou telefone por exemplo). Brandão e Brito (2014) dão uma boa ilustração de como alguns desses institutos não estão preparados para enfrentar o problema do terrorismo. Analisando a lei de interceptação telefônica (n. 9 296/96 e 10 217/01), os autores demonstram como a pré-existência de uma investigação e processo penal são pré-requisitos para a autorização da interceptação. Isso ocorre devido à exigência da Constituição Federal de que as interceptações telefônicas somente são possíveis através de ordem judicial para fins de investigação criminal ou instrução processual penal (artigo $5^{\circ}$, XII, Constituição Federal). Assim, ficam excluídas as hipóteses de interceptação para assessoramento e levanta-se a questão da legalidade da interceptação de outras formas de comunicações como informática e telemática (idem, p. 179). Os autores também discutem os limites da lei sobre infiltração policial (Lei n. 12 850/13). Essa lei também condiciona qualquer infiltração a uma investigação policial ou a um requerimento do Ministério Público após esgotado todos os recursos disponíveis. Isso é problemático porque autoriza apenas a infiltração de policiais excluindo a regulamentação da infiltração de oficiais de inteligência (idem, p. 181). Como destacam os autores, em ambos os casos a legislação foi desenhada para apurar um delito ou crime em andamento ${ }^{11}$ tendo pouco ou nenhum efeito na prevenção de um atentado que ainda não ocorreu. Ademais, soma-se a essas limitações a inexistência de legislação para a guarda e criação de um banco de dados para o tratamento das informações e inteligência geradas pela interceptação e infiltração o que seriamente restringe a produção de conhecimento e inteligência em casos futuros relacionados (idem, p. 181). Assim, a inexistência de um marco jurídico sistemático fundamentado em uma estratégia mais ampla, e que vá além da mera tipificação do crime de terrorismo, traz sérias restrições não 
somente às atividades das agências policiais e de inteligência na prevenção e combate a esse fenômeno. Essa limitação também acaba por afetar as respostas e políticas públicas de áreas correlatas, como a proteção de fronteiras e infraestrutura, a resiliência, o amparo e acompanhamento das vítimas, a administração de crises, a reconstrução, entre outras.

Em rigor, a Constituição Brasileira é expressa e firme ao reconhecer o repúdio ao terrorismo como um dos princípios básicos das relações internacionais do Brasil (art. $4^{\circ}$, VIII). A Constituição operacionaliza esse repúdio ao constituir o terrorismo como um crime hediondo do qual não há a possibilidade de se conceder fiança, graça, anistia ou indulto e dos quais se punem não apenas os autores mas também os mandantes e "os que, podendo evitá-los, se omiti[ram]" (Art 5 $5^{\circ}$ inc. XLIII). O repúdio ao terrorismo também foi reforçado na própria Lei de Crimes Hediondos (Lei n. 8 072, de 25 de julho de 1990) em seus artigos $2^{\circ}, 5^{\circ}(\mathrm{V})$ e $8^{\circ}$. Todavia, essa operacionalização permanece mais teórica do que prática: tanto o crime de terrorismo quanto o crime de auxílio ao terrorismo não foram tipificados e, portanto, não podem ser aplicados.

O mesmo acontece em outros dispositivos legais existentes na legislação brasileira. A controversa Lei de Segurança Nacional (n. 7 170/83), por exemplo, prevê em seu artigo 20 que "atos de terrorismo, por inconformismo político ou para obtenção de fundos destinados à manutenção de organizações políticas clandestinas ou subversivas" são considerados crimes com pena de reclusão de três a dez anos. Esse é um dispositivo especialmente controverso. Além de sua pena parecer especialmente branda, o artigo não define o que são "atos de terrorismo" levando a diversos autores a questionarem a constitucionalidade desse e vários outros artigos da Lei de Segurança Nacional frente a sua anterioridade à Constituição de 1988. Ademais, segundo o artigo $1^{\circ}$, os crimes de terrorismo previsto nessa lei apenas se aplicariam caso lesassem ou expusesse a perigo de lesão:

I - A integridade territorial e a soberania nacional;

II - O regime representativo e democrático, a Federação e o Estado de Direito;

III - A pessoa dos chefes dos Poderes da União (art $1^{\circ}$ ).

Outro caso interessante é a Lei n. 10 744, pela qual a União assume a responsabilidade de terceiros no caso de atentados terroristas, atos de guerras ou eventos correlatos contra aeronaves brasileiras ou operadas por empresas brasileiras. Essa lei, que se inspirou na Terrorism Risk Insurance Act (TRIA) estadunidense, aplica-se apenas aos casos de terrorismo envolvendo aeronaves. Segunda a lei, a União está autorizada a:

"Assumir despesas de responsabilidades civis perante terceiros na hipótese da ocorrência de danos a bens e pessoas, passageiros ou não, provocados por atentados terroristas, atos de guerra ou eventos correlatos, ocorrido no Brasil ou no exterior, contra aeronaves de matrícula brasileira operadas por empresas brasileiras de transporte aéreo público, excluídas as empresas de taxi aéreo" (Artigo $1^{\circ}$ ).

Essa responsabilidade é limitada a US\$ 1 bilhão e devem ser pagos através de títulos do Tesouro Nacional. O ponto de destaque dessa lei é que ela define terrorismo. Em seu o parágrafo $4^{\circ}$ do artigo $1^{\circ}$, terrorismo é definido como sendo "qualquer ato de uma ou mais pessoas, sendo ou não agentes de um poder soberano, com fins políticos ou terroristas, seja a perda ou dano dele resultante acidental ou intencional". Todavia, apesar dessa definição e de sua aplicação restrita aos casos envolvendo aeronaves, a lei ainda estipula que cabe ao 
Ministro da Defesa atestar se os atos em questão ocorreram ou não em virtude de atos terroristas ou de guerra.

Outro dispositivo legal que trata da questão é a recente Lei da Criminalidade Organizada (n. 12 850, de 2013). Essa lei foi criada para clarificar questões relativas à investigação e procedimentos penais de organizações criminosas além de estabelecer algumas infrações penais correlatas (artigo $1^{\circ}$ ). Segundo a lei, esses procedimentos e infrações também se aplicam

"Às organizações terroristas internacionais, reconhecidas segundo as normas de direito internacional, por foro do qual o Brasil faça parte, cujos atos de suporte ao terrorismo, bem como atos preparatórios ou de execução de atos terroristas, ocorram ou possam ocorrer em território nacional" (Artigo $1^{\circ}$, parágrafo $2^{\circ}, \mathrm{II}$ ).

Esse dispositivo marca um avanço na legislação penal brasileira já que reconhece tanto a possibilidade de organizações terroristas internacionais atuarem no Brasil quanto também abarca atos preparatórios e de apoio (suporte) ao terrorismo. Todavia, a lei deixa a definição de quem são as organizações terroristas internacionais a cargo do "direito internacional reconhecido pelos foros de que o Brasil é parte", o que é um tanto vago. Essa indefinição é importante porque esse é exatamente um dos pontos que têm suscitado constantes críticas por parte de outros países e órgãos internacionais como a ONU e o FATF. Segundo esses, o Brasil tem se recusado a reconhecer publicamente grupos como as FARC, Hamas ou Hezbollah como sendo terroristas (American Embassy in Brasilia 2008, p. 2). A formulação desse dispositivo legal e o comportamento oficial brasileiro nos leva a pensar que as únicas organizações terroristas internacionais reconhecidas pelo Brasil segundo essas regras seriam o Talibã e a Al Qaeda, já que ambas foram expressamente condenadas em diversas resoluções obrigatórias adotadas pelo Conselho de Segurança da ONU, invocando o Capítulo VII da Carta. Note-se que, pela própria natureza do dispositivo que é dirigido para organizações criminosas, exclui-se de seu âmbito de aplicação os casos ligados a indivíduos não ligados a grupos ou redes terroristas, os chamados Lone Wolves. Embora reiteramos que a lei é direcionada a organizações, quando relembramos os ataques terroristas de Oslo em 2011 perpetrados por Anders Behring Breivik ou o atentado da Maratona de Boston realizado pelos irmãos Tsarnaev, em 2013, percebemos a importância dessa lacuna. Apesar de serem geralmente menos letais que terroristas profissionais, os Lone Wolves são uma importante ameaça porque tendem a serem de mais difícil detecção pelas agências de inteligência e estão livres das restrições organizacionais o que os tornam mais indiscriminados na escolha de seus alvos e modo de ataque.

É importante destacarmos ainda que tanto os tratados internacionais relacionados ao combate ao terrorismo ratificados pelo Brasil quanto as resoluções obrigatórias do Conselho de Segurança da ONU e outras organizações internacionais, tecnicamente também integram formalmente nossa legislação doméstica. De fato, o Brasil ratificou pelo menos 15 convenções e protocolos internacionais de combate ao terrorismo. São eles: Convenção Relativas às Infrações e Certos Outros Atos Cometidos a Bordo de Aeronaves; Convenção para Repressão ao Apoderamento Ilícito de Aeronaves; Convenção para Prevenir e Punir os Atos de Terrorismo Configurados em Delitos contra as Pessoas e a Extorsão Conexa Quando Tiverem Eles Transcendência Internacional; Convenção para a Repressão de Atos Ilícitos contra a Segurança da Aviação Civil; Convenção sobre a Prevenção e Punição de Infrações contra Pessoas que Gozam de Proteção Internacional, incluindo os Agentes Diplomáticos; Convenção contra a Tomada de Reféns; Convenção sobre a Proteção Física dos Materiais Nucleares; Protocolo para a Supressão de Atos Ilícitos de Violência nos Aeroportos a Serviço da Aviação Civil; Convenção sobre a Marcação dos Explosivos Plásticos para Fins de Detecção; Convenção Interamericana Contra 
12 Ver o Decreto Legislativo n. 267 , de 10 de junho de 2009, que ainda aguarda o Decreto Executivo.

${ }^{13}$ Mesmo quando a expressão "terrorismo" é empregada, o termo não é definido. Ver o art. 33 da IV Convenção de Genebra de 1949, ou o protocolo 2 às Convenções de Genebra de 12 de dezembro de 1977.

${ }^{14} \mathrm{Na}$ realidade, nestas convenções, trata-se mais precisamente do princípio de extraditar ou perseguir (aut dedere aut prosequi). a Fabricação e o Tráfico Ilícito de Armas de Fogo, Munições, Explosivos e Outros Materiais Correlatos; Convenção Internacional sobre a Supressão de Atentados Terroristas com Bombas (com reserva ao parágrafo 1 do artigo 20); Convenção Internacional para a Supressão do Financiamento do Terrorismo; Convenção Interamericana Contra o Terrorismo; Convenção para a Supressão de Atos Ilícitos contra a Segurança da Navegação Marítima; Protocolo para a Supressão de Atos Ilícitos contra a Segurança de Plataformas Fixas localizadas na Plataforma Continental. Ademais, o Brasil assinou, em 13 de abril de 2005, a Convenção Internacional para a Supressão de Atos de Terrorismo Nuclear, mas ainda não a ratificou ${ }^{12}$.

Entretanto, é importante lembrarmos que, diante da dificuldade e impasse em se construir um conceito universalmente aceito e preciso de terrorismo, a técnica utilizada na elaboração desses tratados foi a de se referir às infrações determinadas (como, por exemplo, o sequestro de aeronaves) sem, contudo, mencionar-se o termo terrorismo ${ }^{13}$. Outra importante técnica presente em diversos tratados de combate ao terrorismo foi a determinação da obrigatoriedade de se extraditar ou julgar (aut dedere aut judicare ${ }^{14}$ os indivíduos que cometam as infrações neles previstas como forma de permitir o início de processos penais no âmbito interno dos países. Essas observações são importantes porque, na maioria dos casos, esses tratados não são auto executáveis e criam obrigações de resultado ficando a cargo dos países que os ratificaram a obrigação de implementar as políticas públicas, legislativas e policiais necessárias para obtenção do resultado previsto. A não implementação desses dispositivos ou a não incorporação desses tipos penais em nossa legislação podem ter várias consequências como, por exemplo, a dificuldade na extradição de suspeitos de terrorismo devido ao princípio da dupla criminalidade ou mesmo em última instância a responsabilização internacional do Brasil.

Além dos tratados, após 11 de Setembro outra fonte do direito internacional cria um claro aumento das obrigações internacionais que vinculam o Brasil em matéria de combate ao terrorismo internacional. Houve uma clara mudança na preferência da técnica legislativa internacional no que se refere à criação de normas internacionais sobre esse assunto. O processo de criação normativa mais ágil (se bem que muitas vezes menos democrático) combinado com a possibilidade de sanções institucionais em caso de descumprimento levaram a comunidade internacional a consolidar uma clara preferência por criar obrigações internacionais através de resoluções das organizações internacionais vis-à-vis ao uso de tratados. Embora não caiba aqui explorar os importantes e complexos efeitos dessa mudança, o fato é que o aumento quantitativo do número de resoluções relacionadas a essa matéria consequentemente gerou diversas novas obrigações para os Estados. A título de ilustração, podemos citar algumas obrigações advindas de resoluções do Conselho de Segurança que exigem que os Estados: implementem medidas legislativas, financeiras, de inteligência e de polícia para o combate ativo do terrorismo; adotem medidas contra o terrorismo nuclear; cooperem internacionalmente na luta contra o terrorismo; combatam, previnam e criminalizem os atos de incitamento ao terrorismo e de terrorismo; criminalizem a viagem de indivíduos para o ingresso em campos de treinamento ou em grupos terroristas no exterior; adotem medidas para garantir que terroristas não tenham acesso ao território nacional; evitem a livre movimentação de terroristas dentro do país; implementem medidas de controle das fronteiras; estabeleçam medidas de verificação de documentos; não garantam status de refugiado ou asilo para pessoas envolvidas ou que apoiaram, organizaram ou facilitaram atos terroristas (UNODOC 2009, p. 21).

Longe de ser uma lista exaustiva, esses exemplos, assim como nos tratados, são obrigações de resultado que vinculam o Estado membro da ONU a tomar 
15 Ver artigo 2 do referido tratado. todas as medidas necessárias para seu cumprimento e implementação. Isso é relevante porque, como visto acima, o Brasil ainda apresenta uma enorme lacuna no que tange a legislação de combate e prevenção ao terrorismo. A lista também é bastante ilustrativa demonstrando que a questão da criação de uma legislação de anti e contra terrorismo é algo bastante complexo e que deve ir muito além da mera criminalização desse ato. Um ótimo exemplo para entender as consequências e implicações que a falta dessa legislação específica podem ter é o caso da legislação de combate ao financiamento do terrorismo. O Brasil ratificou em 2005 a Convenção da ONU para a Supressão do Financiamento do Terrorismo. Esse tratado, em conjunto com as resoluções n. 1373 (2001) e 1 267 (1999) do Conselho de Segurança e combinado com a exigência de assistência legal mútua em casos de financiamento de terrorismo estipulada em diversos outros tratados dos quais o Brasil é parte, criam a obrigação de criminalizar diversos aspectos do financiamento do terrorismo ${ }^{15}$.

No entanto, o Brasil ainda não criminalizou de maneira consistente o financiamento do terrorismo. Pelo contrário, de fato, tecnicamente o Brasil descriminalizou o financiamento do terrorismo. O artigo $1^{\circ}$, II e III da lei de combate aos crimes de lavagem de dinheiro (Lei n. 9 613, de 1998) que previa explicitamente o terrorismo e o financiamento do terrorismo como crimes financeiros foi revogado pela Lei n. 12 683, de 2012. Quando questionado nos foros internacionais sobre o assunto, as autoridades brasileiras geralmente alegam não haver necessidade de tal tipificação já que o Brasil possui uma boa rede de inteligência financeira e um sistema de combate à lavagem de dinheiro bem estruturado e consolidado. Ademais, argumenta-se que a formulação da nova lei é mais geral e ampla o que implicitamente incluiria o financiamento do terrorismo. Finalmente, as autoridades brasileiras afirmam ainda que o financiamento do terrorismo não é um problema no Brasil. Isso porqu a COAF fez uma procura das pessoas e entidades constantes na lista de financiadores do terrorismo originadas das resoluções n. 1267 e 1373 do Conselho de Segurança e não encontrou nenhum bem, conta ou propriedade constante da mesma (American Embassy in Brasilia 2008, p. 2).

Contudo, internacionalmente, o governo brasileiro tem sido alvo de muitas críticas por essa postura (American Embassy in Brasilia 2009b, p. 1; FATF \& GAFISUD 2010, p. 43). Além do governo estadunidense, a FATF tem frequentemente objetado a postura brasileira nesse assunto. Apesar de reconhecer os esforços brasileiros no que tange a lavagem de dinheiro, a FATF frequentemente aponta que o Brasil ainda não criminalizou o financiamento do terrorismo de uma maneira consistente com suas recomendações. Por exemplo, em seu último relatório publicado sobre o Brasil, o "FATF Mutual Evaluation Report: Brazil", essa instituição reiteradamente alerta que a falha do Brasil em criminalizar "impacta seriamente a habilidade do Brasil de investigar e processar o financiamento do terrorismo. Isso também mina sua habilidade de adotar medidas cautelares, confiscar bens e prover cooperação internacional (extradição) nestes casos" (FATF \& GAFISUD 2010, p. 26).

A frustração da FATF se deve por conta do que veem como uma insistência do Brasil em não se criminalizar alguns dos crimes de financiamento do terrorismo previstos pelas suas "Special Recommendations". Essas recomendação estipula que para se estabelecer um efetivo combate internacional ao financiamento do terrorismo, é necessário que os países adotem, além da criminalização do financiamento do terrorismo em si, os crimes de provisão ou coleta de fundos que: (i) sabidamente irão ser utilizadas para um ato terrorista; (ii) feitos por uma organização terrorista para qualquer fim (ou seja, bem, fundos ou recursos que não necessariamente serão utilizados em um ato terrorista); (iii) feitos por um indivíduo terrorista para qualquer outro fim; (iv) feitos para o financiamento de um ato terrorista que ainda não foi cometido ou 
tentado. Segundo a FATF, a falha em implementar essa legislação acaba por seriamente limitar a capacidade do Brasil de congelar e/ou apreender bens e fundos ligados ao financiamento do terrorismo.

Segundo a FATF, o Brasil incorporou os textos das resoluções n. 1267 e 1 $373 \mathrm{em}$ sua legislação mas não os meios necessários para que estas sejam efetivas. A FATF aponta, por exemplo, que as autoridades financeiras brasileiras não têm poder suficiente para congelar bens ligados ao terrorismo já que não há distinção entre a apreensão de bens por terrorismo ou qualquer outra atividade criminosa (idem, p. 54). Qualquer ação nesse sentido seguirá os procedimentos previstos para os casos de lavagem de dinheiro. Assim, a falta de legislação específica faz com que o Brasil não tenha dispositivos legais para autorizar o congelamento de bens somente com base no fato desses estarem relacionados a uma organização ou indivíduo terrorista mas sem a conexão com um ato terrorista (idem, p. 55). A FATF também se mostra cética quanto a capacidade brasileira de congelar bens "sem atraso" e "dentro de horas de sua designação pelo Comitê de sansões da Al Qaeda e Talibã", conforme requerido pela resolução n. 1267 (1999) do Conselho de Segurança (idem, p. 58; Special Recommendation III). Ademais, também não há qualquer provisão específica na legislação brasileira para dar prosseguimento ao congelamento de bens iniciados em outras jurisdições ou mesmo procedimentos para a listagem e de-listagem/descongelamento de bens e fundos de indivíduos ou organizações listados internacionalmente como financiadores do terrorismo.

Outro ponto crítico da falta de legislação para a FATF é a dúvida de se as autoridades brasileiras possuem os instrumentos necessários de controle sobre as Organizações Não-Governamentais sem fins lucrativos (ONGs). A relação de diversas ONGs com o financiamento do terrorismo têm sido uma preocupação constante das autoridades internacionais. Há um receio de que no caso do envolvimento de uma ONG atuando em território brasileiro tivesse alguma conexão com o financiamento do terrorismo, o governo brasileiro teria um poder limitado de investigação e ação devido à falta de legislação específica (idem, p. 219). Assim, não há dúvidas da importância em se distinguir entre a lavagem de dinheiro e o financiamento de atividade terrorista. Como visto, existem importantes peculiaridades nos casos de financiamento do terrorismo aos quais se adicionam, por exemplo, os baixos valores implicados nessas transações (se comparado com crime organizado) e o fato de grupos terroristas muitas vezes se utilizarem de meios legais de financiamento e transferência de dinheiro.

Por fim, dado o caráter transnacional do sistema financeiro atual (tanto legal quanto ilegal), a falta de legislação pode resultar também em problemas de cooperação internacional. Um exemplo é o caso da extradição. É verdade que o Brasil poderia extraditar indivíduos ligados ao financiamento do terrorismo e outras atividades correlatas devido a sua interpretação ampla do princípio da dupla criminalidade (idem, p. 244). Todavia, pela legislação brasileira e sua aplicação, a possibilidade de se extraditar um indivíduo por crimes de terrorismo não previstos na nossa legislação somente seria viável nos casos em que o ato terrorista já tenha sido cometido ou tentado. Dessa forma, várias lacunas permanecem como, por exemplo, situações em que tentado ainda não foi executado, situações de uso de dinheiro por grupo ou indivíduo terrorista para atividade não terrorista ou mesmo naquelas situações em que o acusado for brasileiro (ibidem).

Aliás, o problema da extradição nos casos de crimes ligados ao terrorismo apresenta uma outra grande dificuldade, a de que, sem entrarmos no problema da sua definição, o terrorismo é, por natureza, uma ação eminentemente política. Entretanto, um dos princípios da extradição é exatamente a chamada 
16 Ver também Mora (1962), Cantrell (1977) e Rebane (1995). exceção da ofensa política, ou seja, não se extradita por crimes de natureza política. Isso pode se tornar um grande entrave frente a obrigação de se extraditar ou julgar indivíduos prevista nos tratados de combate ao terrorismo. Essa é uma das exceções mais tradicionais e está presente na grande maioria dos tratados de extradição. O ponto central por trás desse impedimento é que ninguém seja punido por suas ideias políticas. Contudo, existe uma grande dificuldade em se definir exatamente o que são "crimes de natureza política" (Griffith \& Harris 2005) já que a maioria dos tratados não se preocupam em definir esses crimes ou o fazem de uma maneira negativa, isto é, descrevendo o que não é considerado como crime político. Adicionalmente, à exceção de algumas poucas práticas como atentados a chefes de Estado, existe pouco consenso em torno do que sejam crimes de natureza política. Desse modo, a exceção das ofensas políticas pode cair em duas categorias: a dos crimes puramente políticos e a das ofensas relativamente políticas. Segundo Gupta (2000), os primeiros são aquelas ofensas dirigidas aos Estado e não possuem os elementos normais de um crime. Essas ofensas, tais como traição e espionagem, raramente são extraditáveis. Já a segunda categoria engloba a maioria das alegadas ofensas políticas e são aquelas que possuem elementos de um crime comum e normalmente extraditável mas inseparáveis do elemento político.

No caso concreto, caberá aos juízes determinar se os atos do indivíduo recaem ou não sobre essa categoria. De um modo geral, os métodos utilizados pelos países de Civil Law variam enormemente e costumam ser aplicados caso a caso. Contudo, um dos princípios que mais encontra aplicação nessa determinação é o chamado "teste de proporcionalidade" que estabelece que o componente da ação criminal dever ser pesado em relação ao componente político dos atos, isso é, aos ganhos políticos desejados pelo indivíduo. Assim, para que a ação se caracterize como uma exceção política, o elemento político deve predominar (idem). Ademais, normalmente se exige que o ato seja cometido durante uma luta pelo poder político ou para se escapar de um regime repressivo (idem, p. 27) ${ }^{16}$

Essa é uma discussão extremamente relevante para o combate ao terrorismo internacional - e que já se fez presente no Brasil. Cada vez mais tem se consolidado, na sociedade internacional, o entendimento de que o dever de combater atos de terrorismo deve se sobrepor a essa exceção - mesmo naqueles casos que apresentam um forte elemento político. No mesmo sentido, vários Estados promoveram legislações e acordos removendo a aplicação da exceção política em casos de terrorismo. No Brasil, apesar de não haver uma legislação específica sobre o assunto, o próprio Supremo Tribunal Federal decidiu, em um caso marco, que atos de terrorismo não fazem jus à exceção da ofensa política para efeitos de extradição, mesmo embora o termo seja muitas vezes definido como sendo um crime com motivação política. Segundo o próprio STF:

\footnotetext{
"Os atos delituosos de natureza terrorista [...] não se subsumem à noção de criminalidade política. [...] A Constituição da República [...] não autoriza que se outorgue, às práticas delituosas de caráter terrorista, o mesmo tratamento benigno dispensado ao autor de crimes políticos ou de opinião" (Brasil 2005, pp. 21-22).
}

Essa decisão, sem dúvida, marca um importante avanço na matéria. Todavia, conforme visto acima, ainda permanecem diversas lacunas no que diz respeito à extradição de terroristas que se encontram em solo brasileiro. Ademais, casos como o do italiano Cesare Battisti que, acusado de terrorismo na Itália, teve o parecer favorável do STF à sua extradição, mas a negativa do presidente Luiz Inácio Lula da Silva, demonstram como o fator político ainda desempenha uma importante influência sobre o andamento jurídico dessa matéria no Brasil. Assim, tendo em vista o exposto acima, fica claro a necessidade de se implementar legislação específica sobre a matéria. 


\section{Outras legislações em debate}

É importante mencionarmos que, até o momento em que esse artigo foi escrito, existem diversos projetos de lei sobre a matéria no Congresso Nacional. Entre eles, podemos citar: o projeto de lei visando negar vistos para pessoas ligadas ao terrorismo (introduzido em 2011); o projeto para a definição de terrorismo na Constituição (introduzido em 2013); o projeto de reforma do código penal que inclui em sua parte ligada aos crimes internacionais a tipificação de atos de terrorismo (introduzida em 2012); o projeto para definição e combate ao terrorismo durante a Copa do Mundo (introduzida 2011); e o projeto de emenda da Lei Federal n. 9 613/1998 para criminalizar o financiamento de terrorismo. Não obstante, como pode ser observado pelas datas em que os projetos de lei foram introduzidos, há uma grande demora em suas promulgações. Os Estados Unidos, por exemplo, são explícitos em considerarem o fato de a legislação de antiterrorismo e anti-lavagem de dinheiro estarem prontas mas não votadas como sendo a principal falha do contraterrorismo brasileiro e um reflexo da falta de vontade política em se aprovar esse tipo de lei. Ainda segundo os Estados Unidos, essa inércia deliberada acontece devido a alegações históricas e ideológicas de que essa legislação poderia ser usada contra a oposição e movimentos sociais (American Embassy in Brasilia 2009b, p. 1).

Além da resistência em aprovar esse tipo de legislação, uma análise do conteúdo desses projetos e das discussões envolvendo os mesmos demonstram que há uma excessivo enfoque e insistência na criação de leis que tipifiquem o crime de terrorismo. Contudo, é absolutamente necessário compreender as especificidades desse fenômeno e desenhar um conjunto de normas coerente, integrado e cuja arquitetura acompanhe uma estratégia mais ampla de prevenção e combate ao terrorismo. Assim, baseando-se nas recomendações do Escritório da ONU para as Drogas e o Crime Organizado (UNODOC 2009) e na nossa experiência, qualquer legislação sobre a matéria deve ser capaz de endereçar pelo menos os seguintes aspectos do combate ao terrorismo:

- Ofensas por atos terroristas já cometidos. Por exemplo: ofensas violentas que não requerem intenção terrorista; atos de assistência direta e indireta a atos terroristas; responsabilidade criminal pela direção e organização de atos terroristas; persecução criminal múltipla de atos em uma única série de eventos etc.;

- Ataques suicidas e os limites das ações reativas;

- Ofensas terroristas não tradicionais. Por exemplo: ataques químicos, biológicos, radiológico ou nucleares; ciberterrorismo, entre outros;

- Ofensas para prevenir atos terroristas. Por exemplo: associação para preparar atos terroristas (Civil Law); conspiração para cometer atos terroristas (Common Law); associação ou apoio a organizações ilegais; financiamento ou apoio ao terrorismo; preparação individual de atos terroristas; incentivo ou apologia ao terrorismo; divulgação de material sensível ou proibido; viagem para treinamento em campo de treinamento terrorista ou para engajamento em atividade terrorista ou de insurgência; proteção de fronteiras; proteção de infraestrutura, etc.

- Relação entre terrorismo e outras formas de crime. Por exemplo: corrupção; terrorismo e narcotráfico; terrorismo e crime organizado; uso de contravenções menores para capturar grandes criminosos; falsificação de documentos e ofensas de imigração etc.;

- Marco jurídico do processo penal/civil. Por exemplo: relação com a atividade de coleta de inteligência para investigação criminal; demora processual, entre outros; 
- Questões de investigação e inteligência. Por exemplo: obstáculos investigativos; leis sobre interrogatório e proteção; procedimentos processuais e administrativos; meios de interceptação, infiltração, obtenção de provas e inteligência etc.

- Cooperação internacional. Por exemplo: a obrigação de extraditar ou julgar; a exceção do crime político; expulsões; garantias diplomáticas; incorporação de tratados e resoluções, entre outros.

- Aspectos da responsabilidade civil e apoio às vítimas. Por exemplo: auxílio às vítimas; seguro; gestão e resposta de crise; reconstrução e resiliência etc.

Portanto, qualquer legislação sobre o assunto não pode deixar de abordar de maneira sistemática os diferentes e múltiplos aspectos que envolvem esse fenômeno e o seu combate. Adicionalmente, a criação dessa legislação também deve estar atenta para a realidade das limitações estruturais e institucionais brasileiras no combate ao terrorismo além de endereçar não somente os ataques mas também os atos relacionados em todas as fases do ciclo da atividade terrorista. Logo, é necessário que haja mais debate para a construção de uma legislação sistemática e que inclua em sua arquitetura normativa: (i) a interação com outras legislações relacionadas; (ii) a preocupação em identificar e atuar efetivamente em todas as diferentes fases do ciclo de atividade terrorista; (iii) as particularidades da investigação, obtenção de provas e processo criminal, civil etc., que o combate ao terrorismo envolve; $(i v)$ abordar a questão da cooperação internacional, além de levar em conta as próprias fraquezas e particularidades institucionais de nossas agências de inteligência, polícia e judiciárias. Essas são questões difíceis e delicadas mas que precisam ser enfrentadas devido as especificidades do terrorismo internacional.

\section{A importância do contexto internacional do terrorismo para o Brasil}

Apesar de o fenômeno do terrorismo ser algo bastante antigo, o modus operandi de grupos terroristas tem sido bastante dinâmico e adaptativo ao longo da história. A grande capacidade de adaptação tática e organizacional de certos grupos terroristas ainda é uma constante e, de fato, as características, realidades e ameaças postas pelo terrorismo internacional têm se modificado de maneira rápida nos últimos anos. Entre as mudanças recentes podemos destacar tanto um grande aumento no número de grupos terroristas quanto uma grande diversificação e difusão de seus modi operandi. O número de grupos terroristas que se dizem de matiz salafistas jihadistas, por exemplo, aumentou em 58\% desde 2010. Ainda, segundo o Institute for Economics and Peace, somente no ano passado houve um aumento do número de mortes relacionadas ao terrorismo foi da ordem de $61 \%$ e o número de países que sofreram atentados passou de 15 para 24 (IEP 2014). Esse incremento também foi acompanhado de um expressivo aumento do número de ataques realizados por esses grupos (Jones 2014, p. viii). Contudo, mais significativo é o grande aumento da complexidade causada por essas mudanças. O que se tem observado é a circunscrição de movimentos e queixas locais em uma ideologia extremista mais ampla. Esse movimento acaba por levar a uma radicalização da ação desses grupos em nome de uma ideologia presumidamente universal mas que resulta na preservação de importantes características e idiossincrasias locais específicas a cada grupo. Esse processo complica enormemente as políticas e ações de combate ao terrorismo devido ao incremento da diversidade e heterogeneidade dos grupos terroristas ativos em suas composições, ideologias, áreas de atuação, modus operandi, forma de organização, grau de ameaça, nível de radicalização etc. 
Contudo, observa-se que essa diversificação foi acompanhada de uma certa contenção regional dos atentados. Há, nos últimos anos, uma concentração dos ataques desses grupos ao chamado inimigo próximo (Jones 2014, p. viii). Se isso, por um lado, pode ser visto como um certo reforço ao distanciamento do Brasil de ataques terroristas, por outro pode aumentar a fragilidade dos crescentes empreendimentos brasileiros na África e Oriente Médio. Não podemos nos esquecer de que o sequestro de empresários, extorsão de empresas e ataques à infraestrutura são táticas bastante comuns no financiamento de grupos terroristas na região do Sahel e Leste Africano. Como lembra Souza (2009, p. 30), o Brasil, seus cidadãos e empresas não estão a salvo de serem vítimas em atentados ocorridos no exterior. Basta lembrarmos que brasileiros estavam entre os mortos nos ataques de 11 de Setembro, nos atentados em Bali em 2002 e em Madrid em 2004, além das mortes de Sérgio Vieira de Mello no atentado ao escritório da ONU em Baghdad, em 2003, e Jean Charles de Menezes em Londres, em 2005. É importante destacar ainda que essa concentração de ataques no inimigo próximo de maneira alguma isenta a possibilidade de que atentados sejam realizados contra um inimigo distante. E muito menos significa a ausência de outras atividades terroristas em territórios que não sofrem ataques.

Outros aspectos da dimensão internacional do fenômeno terrorista também são de grande interesse para o futuro do Brasil. Regionalmente, por exemplo, a extensa e porosa fronteira do Brasil com países que têm um histórico de grupos violentos como Peru, Colômbia e Venezuela traz a preocupação da infiltração do território brasileiro por indivíduos e/ou grupos extremistas ou mesmo da utilização do Brasil como rotas de apoio às suas atividades. Da mesma forma, a recente explosão no número de imigrantes e refugiados vindo de países em conflito como a Síria acompanhados por uma falta de sistematização de inteligência sobre os mesmos pode apresentar-se como uma porta de entrada de indivíduos com conexões com grupos terroristas no país que podem tanto vir a estabelecer células operacionais no território brasileiro, quanto servir de ponte de contato com grupos radicais no exterior. Basta lembrarmos da declaração feita pelo presidente do Iêmen, Abdu Rabbu Mansour Hadi, em abril deste ano, informando que três brasileiros estavam entre os 30 membros da Al Qaeda mortos naquele país após uma operação realizada contra esse grupo, para dar credibilidade a essa possibilidade.

De modo semelhante, o crescente papel do Brasil em missões de paz, e sua crescente busca por liderança e inserção internacional, podem acabar por gerar ressentimento ou oportunidades para indivíduos e grupos que se utilizam do terrorismo. Assim, mesmo diante de um quadro de relativa ausência de uma violência política mais explícita, esse cenário pode vir a ser alterado e agravado devido a oportunidade que grandes eventos como as Olimpíadas podem oferecer a esses grupos. Ainda que consideremos que grupos terroristas não têm a intenção de agir diretamente contra o Brasil, não há como negar que esses eventos oferecem um grande apelo e alcance midiático para que esses grupos transmitam sua mensagem ideológica. De fato, como Baylis et al. (2002, p. 6; tradução livre) colocam, "manifestantes e terroristas já intervieram nos Jogos, roubando o foco da mídia e direcionando atenção para suas [respectivas] causas", isso porque "atores terroristas não tencionam apenas ameaçar certa categoria de pessoas ou atemorizar 'o outro lado'. Eles tentam também transmitir uma mensagem a seu próprio lado, a potenciais aliados, ou aos governos que possam apoiar, ou mesmo patrocinar, suas ações" (Wieviorka 1995, p. 599). A presença da mídia mundial somada à visita de delegações estrangeiras de países de alta evidência como os Estados Unidos e Israel potencializam enormemente a possibilidade de ocorrência de atentados em solo brasileiro. Se, por um lado essa é uma preocupação que se encontra explícita também no próprio Relatório da Comissão de Avaliação do Comitê Olímpico 
Internacional (COI) para 2016 (Assuntos Gerais, item 10, “Terrorismo”, p. 7), essa preocupação também se encontra explicitado nos próprios manuais e publicações de grupos radicais com a Al Qaeda.

Portanto, é essencial o monitoramento e conscientização das reais ameaças que o fenômeno do terrorismo representa. É importante a sensibilização do governo para o apoio dos órgãos direta e indiretamente envolvidos com os processos de inteligência e capacitação de segurança pública no intuito de minimizar os riscos existentes. Lembremos que ataques a eventos esportivos não é algo novo ou mesmo raro. Só para mencionar alguns atentados a oficiais, atletas, turistas e locais lotados em grandes eventos podemos relembrar os atentados: de 1972 em Munique, de 1983 em El Salvador, de 1986 em Amsterdam, de 1992 em Barcelona, de 1996 na Colômbia, de 1996 em Atlanta, de 2006 no Iraque, de 2008 em Pequim e de 2013 em Boston. Em todas essas ocasiões, as autoridades considerava altamente improvável a ocorrência de um ataque terrorista.

De fato, há uma tensão entre a postura vigilante das agências policiais e de inteligência brasileiras e a postura negacionista da União. Essa tensão tem resultado em uma participação brasileira de certa maneira vacilante nos foros internacionais. Oficialmente, o Brasil participa de vários foros internacionais e regionais que lidam com o assunto tais como os órgãos relevantes da ONU e do FATF, o Comitê Interamericano Contra o Terrorismo (CICTE, OEA), a União das Nações Sul-americanas, o Grupo de Trabalho sobre terrorismo e o Subgrupo sobre questões financeiras do Mercosul (que também lida com questões relacionadas ao financiamento do terrorismo) além do Acordo da Tríplice Fronteira. Todavia, a participação do Brasil nesses foros tem sido algumas vezes alvo de críticas. Entre estas podemos mencionar a falta de tipificação dos crimes de terrorismo e financiamento de terrorismo ou o não reconhecimento de certos grupos e organizações como terroristas. Outros exemplos concreto que despertaram um mal estar em alguns foros internacionais foram a recusa do governo brasileiro em endossar as alegações argentinas de envolvimento de indivíduos em território brasileiro no ataque terrorista de 1994 em Buenos Aires e sua abstenção quando da emissão da notícia de captura da Interpol para cinco indivíduos iranianos e um libanês suspeitos de envolvimento no atentado.

O terrorismo internacional também pode ter impacto indiretamente sobre o Brasil de outras formas. Ataques terroristas e os esforços de contraterrorismo produzem diferentes efeitos sobre os mercados globais. Apesar de ser bastante difícil construir um quadro completo e claro dos efeitos macroeconômicos em um mundo altamente interconectado, é fácil entender que qualquer impacto sobre a economia norte-americana com o aumento de gastos de defesa nos Estados Unidos tem impacto sobre o Brasil. Da mesma forma, a implementação de leis domésticas de antiterrorismo nos Estados Unidos (e em outros países), podem influenciar, de uma forma ou de outra, o fluxo do comércio internacional do Brasil com esse país. Alguns exemplos de leis antiterrorismo que afetaram, em maior ou menor grau, as exportações brasileiras para os Estados Unidos, podemos citar: o Trade Act (2002); o Anti-Bioterrorism Act ${ }^{17}$; o Insurance Act, bem como vários programas governamentais como o Container Security Initiative $(2002)^{18}$ e o Customs-Trade Partnership Against Terrorism ${ }^{19}$. Todas estas regulamentações introduziram uma série de restrições não tarifárias à circulação de bens e serviços para e nos Estados Unidos, aumentando o custo e tempo necessário para as operações comerciais e criando barreiras adicionais que aumentam os custos e riscos indiretos dos exportadores, principalmente de produtos perecíveis e transportados via área ou marítima.

Ademais, no nível sistêmico, a ação de grupos terroristas no exterior podem também resultar em inúmeros outros impactos indiretos com grandes impli- 
e dos registros identificando as fontes imediatamente anteriores e o receptor imediatamente posterior desses alimentos.

${ }_{18}$ A Container Security Initiative (CSI), adotada em janeiro de 2002, cria o monitoramento, inspeção e lacre de container destinados aos Estados Unidos no porto de origem.

19 A Customs-Trade Partnership Against Terrorism (C-TPAT) é uma iniciativa público-privada lançada em maio de 2002 que adota novas medidas de segurança para importadores. As empresas participantes apresentam informações sobre sua linha de insumos e fornecem informações sobre a guarda, manuseio, transporte e guarda de seus produtos, incluindo os caminhões e rotas utilizados. cações para nossa política externa e de segurança. A crescente presença de empresas e investimentos brasileiros na África e Oriente Médio, podem vir a sofrer com o incremento de sequestro de executivos, extorsões e mesmo ataque à infraestrutura na região por motivos relacionados ao terrorismo. A instabilidade em países que enfrentam um cenário de insurgência, por exemplo, já tem afetado algumas exportações brasileiras. O mesmo pode afetar a formação internacional do preço do petróleo em um momento em que o Brasil se torna crescentemente envolvido nesse mercado. Em termos de política internacional: conflitos como o da Síria e a falha em resolvê-lo pode levar à desestabilização de vizinhos como Jordânia, Turquia e Israel, o que pode afetar grandemente os interesses brasileiros na região.

Dessa forma, a identificação de gargalos em pontos chave de uma política de contraterrorismo é muito mais do que um debate teórico e acadêmico. As implicações da falta de uma estratégia e arranjo institucional consolidados são bastante reais e práticas. A ausência de institutos jurídicos específicos, a limitação de recursos humanos e materiais, somados a ausência de debates de temas como proteção de infraestrutura e fronteiras, programas de contra radicalização e desradicalização, políticas de resiliência e integração interagências, constituição de unidades de resposta rápida, administração integrada de informações, respostas pós-atentados, acompanhamento de vítimas, treinamento dos "first-respondents" etc. trazem uma enorme vulnerabilidade para nossas políticas públicas de segurança e defesa em geral. Adicionalmente, a reflexão mais sistematizada sobre esse assunto se refletirá não apenas nas políticas públicas de antiterrorismo, mas também trará valiosas lições para políticas de transporte e planejamento urbano, realização de grandes eventos, resposta a crises, resiliência, e principalmente políticas de defesa civil ligadas a grandes desastres.

\section{Conclusões}

O fenômeno do terrorismo internacional é algo que não deve ser subestimado. Sempre marcado por um forte caráter de imprevisibilidade, nunca se sabe quando ou onde suas atividades podem ocorrer. Nesse contexto, o Brasil não está livre dessa ameaça e ainda possui um longo caminho a percorrer para melhorar suas políticas de prevenção e combate a esse complexo fenômeno. Entre alguns dos maiores problemas apontados ao longo do texto, podemos ressaltar a falta de conhecimento especializado sobre o assunto, a inexistência de uma estratégia consolidada para guiar as ações institucionais bem como a carência de um quadro normativo sistêmico para estruturar as ações de prevenção e combate ao terrorismo. Esse, contudo, não é um trabalho fácil. Como nos lembra o Escritório da ONU para as Drogas e o Crime Organizado:

"O terrorismo é um fenômeno complexo e em constante mudança. Suas motivações, financiamento e mecanismos de apoio, seus métodos de ataque e escolha de alvos estão em constante evolução adicionando, portanto, à complexidade de uma estratégia efetiva para seu combate" (UNODOC 2009, p. 5).

No mesmo sentido, a criação de uma legislação integrada de combate ao terrorismo é um trabalho árduo e arriscado. A experiência em outros países nos ensina que existe um grande risco de que a falta de mecanismos de controle e um maior debate sobre esse fenômeno possa levar ao uso criativo e instrumental dessa legislação para fins políticos. Isso deve ser evitado de qualquer forma. A existência dessa legislação é um importante instrumento no combate ao terrorismo internacional mas não deve ser utilizada na intervenção em outras atividade políticas que, em realidade, não se configuram como terrorismo tais como movimentos sociais legítimos.

Adicionalmente, conforme nos lembra a UNODOC, o perigo dessa legislação é ainda maior devido a necessidade de um trabalho próximo entre a 
polícia, forças militares e serviços de inteligência, o que traz o risco de militarização da polícia e de enfraquecimento do controle e vigilância civis desses órgãos (idem, p. 49). Outra complicação é que as especificidade do terrorismo trazem dificuldades para o próprio sistema criminal. Afinal de contas, os sistemas criminais são desenhados para responder e punir crimes após seu acontecimento, mas o objetivo primário de estratégias, políticas e legislações de combate ao terrorismo devem ser exatamente evitar ou prevenir os incidentes. Por isso, muitos dos mecanismos e procedimentos penais existentes são ineficazes ou inadequados para responder a esse fenômeno e daí a necessidade de se criar uma legislação sistemática específica. Não obstante, a justiça criminal ainda é o mecanismo mais apropriado para se conseguir a justiça e a proteção dos direitos dos acusados e vítimas. De fato, a própria ONU destaca que terroristas tais quais definidos pelos instrumentos internacionais são criminosos e devem ser tratados como tais pela justiça criminal dos países (idem, p. 3). Por isso, a luta contra o terrorismo deve ocorrer dentro do marco da justiça criminal assentado nos princípios básicos do Direito e da democracia e em consonância com os direitos humanos e humanitário. Esses princípios e ramos do Direito estão preparados para lidar com esses casos complexos e não podem, de forma alguma, ser vistos como uma barreira à atividade de combate ao terrorismo.

Assim, é preciso proceder com cautela. Da mesma forma que o terrorismo pode ameaçar os direitos e liberdades dos cidadãos, legislações antiterrorismo mal desenhadas ou apressadas podem ameaçar as garantias fundamentais dos indivíduos (idem, p. 6). É necessário criar um regime legal adequado para lidar com esses casos complexos, mas dentro da justiça criminal. Nesse processo, deve-se evitar a militarização excessiva das polícias ou o empoderamento demasiado do poder Executivo pelas políticas de combate ao terrorismo. Qualquer legislação deve ter o cuidado de incluir em seu desenho normativo o devido processo legal, o respeito aos direitos e garantias fundamentais, o direito à ampla defesa e respeito aos direitos humanos. Como destaca a UNODOC, somente assim podemos "reforçar o comprometimento da sociedade com o devido processo legal e os direitos humanos, mesmo sob ameaças terroristas" (idem, p. 5). Deve-se também envolver legisladores, as agências de segurança e inteligência, o Ministério Público e o poder Judiciário. Adicionalmente é preciso pensar e criar mecanismos externos eficientes de controle e accountability para se evitar abusos. Por fim, não basta a criação de um legislação específica, também é necessário treinamento, planejamento, e construção de capacidades institucionais e operacionais. Em realidade, isso não se trata de uma novidade, mas sim de uma obrigação legal. Diversas resoluções da ONU e tratados internacionais consolidaram a obrigação internacional de que as legislações antiterroristas não podem contrariar o Direito Internacional e os direitos humanos ${ }^{20}$.

${ }^{20}$ Ver, por exemplo, as resoluções 59191 e 60/158 da Assembleia Geral, 2004/87 da Comissão de Direitos Humanos, 1456 (2003) e 1624 (2005) do Conselho de Segurança, o artigo 15 da Convenção Interamericana Contra o Terrorismo, o artigo 22 da Convenção da Organização da União Africana sobre a Prevenção e Combate do Terrorismo, e a United Nations Global Counter Terrorism Strategy de 2006.
Essa é uma dificuldade que deve ser enfrentada. Algumas manifestações do terrorismo possuem um crescente componente transnacional. Portanto, seu combate requer grande cooperação entre as justiças criminais dos países (ibidem). Apesar da centralidade dos atos de terrorismo e do fato de serem considerados uma ameaça à paz e segurança internacionais conforme as resoluções n. 1368 e 1373 do Conselho de Segurança, eles não são considerados crimes internacionais e não existem tribunais internacionais com jurisdições específicas para combater esse tipo de crime. Daí a centralidade de se criminalizar esse ato em seus mais diversos componentes. O terrorismo deve ser considerado como crime nacional com repercussão internacional e, por isso, a responsabilidade em se julgar criminosos terroristas recaem principalmente sobre as justiças domésticas dos países (idem, p. 9). Dessa forma, o Brasil não pode se furtar na cooperação internacional no combate ao terrorismo. Para isso, é indispensável a criação de uma estratégia e um regime normativo sistemático 
de prevenção e combate ao terrorismo, bem como a incorporação legislativa e operacional dos tratados e resoluções da ONU, mecanismos de assistência legal mútua, extradição, transferência de prisioneiros, transferência de procedimento legais, confisco de provas e evidências, recuperação de bens etc.

Jorge Mascarenhas Lasmar (jorgelasmar@gmail.com) é Doutor em Relações Internacionais pela London School of Economics and Political Sciences e Professor do Programa de Relações Internacionais da PUC Minas.

\section{Referências}

Baylis, J.; Wirtz, J.; Cohen, E.; Gray, C.S., eds. 2002. Strategy in the Contemporary World. Oxford: Oxford University Press. Brandão, P.; Brito, V. 2014. Terrorismo, inteligência e mecanismos legais: desafios para o Brasil. In C.S. Arturi, ed. Politicas de defesa, inteligência e seguranca. Porto Alegre: UFRGS Editora.

Cantrell, C.L. 1977. The Political Offense Exemption in International Extradition: A comparison of the United States, Great Britain and the Republic of Ireland. Marquette Law Review, 60(3), pp. 777-824.

Coutinho, L. 2011. A rede do terror no Brasil. Veja, 44(14), pp. 88-96.

Diniz, E.P. 2004. Considerações sobre a possibilidade de atentados terroristas no Brasil. In Secretaria de Acompanhamento e Estudos Institucionais. II Encontro de Estudos. Terrorismo. Brasília: Gabinete de Segurança Institucional.

Don, B.W.; Frelinger, D.R.; Gerwehr, S.; Landree, E.; Jackson, B.A. 2007. Network Technologies for Networked Terrorists: Assessing the Values of information and communications technologies to modern terrorist organizations. Santa Monica: Rand Corporation.

Donohue, L.K. 2008. The Cost of Counterterrorism: Power, politics and liberty. New York: Cambridge University Press. Farah, D. 2012. Back to the Future: Argentina unravels. International Assessment and Strategy Center.

Fields, J. 2002. Islamist Terrorist Threat in the Tri-Border Region. Monterrey: Monterry Institute of International Studies. Griffith, G.; Harris, C. 2005. Recent Developments in the Law of Extradition. Melbourne Journal of International Law, 6(1). Gupta, S.K. 2000. Extradition Law and the International Criminal Court. Berkeley Journal of Criminal Law, 3(1), pp. 1-35. Jacini, W.F.B. 2002. Terrorismo: atuação da Polícia Federal. CEJ, 18, pp. 74-82.

Jones, S.G. 2014. A Persistent Threat: The evolution of al Qa'ida and Other Salafi Jihadists. Santa Monica: Rand Corporation. Levitt, M. 2012. The Iranian Security Threat in Western Hemisphere: Learning from past experience. The SAIS Review of International Affairs, 32(1), pp. 157-168.

Mora, M.R.G. 1962. The Nature of Political Offenses: A knotty problem of Extadition Law. Virginia Law Review, 48(7), pp. 1 226-1 257.

Nisman, A.; Burgos, M.M. 2013a. Office of Criminal Investigations. AMIA case. Investigations Unit of the Office of Attorney General. Disponível em: http://www.peaceandtolerance.org/docs/nismanindict.pdf. Acesso em 5 fev 2015. 2013b. Summary. In___. Office of Criminal Investigations. AMIA case. Investigations Unit of the Office of Attorney General. Disponível em: http://www.peaceandtolerance.org/docs/nismanindict.pdf. Acesso em 5 fev 2015.

Raza, S. 2005. Terrorism in the Southern Cone: Prosfictional view and power politics. SCSRC Discussion Paper, 5(55), pp. $1-27$.

Rebane, K.I. 1995. Extradition and Individual Rights: The need for an International Criminal Court to safeguard individual rights. Fordham International Law Review, 19(4), 1 636-1 685.

Rees, W.; Aldrich, R.J. 2005. Contending Cultures of Counterterrorism: Transatlantic divergence or convergence? International Affairs, 81(5), pp. 905-923.

Souza, D.N. 2009. Brazil's Role in the Fight Against Terrorism. Revista Brasileira de Inteligência, 5, pp. 29-38.

Wievirka, M. 1995. Terrorism in the Context of Academic Research. In M. Crenshaw, ed. Terrorism in Context. University Park: Pennsylvania State University Press.

\section{Outras fontes}

9/11-Commission. 2005. Final Report on 9/11 Commission Recommendations. Washington, D.C.: National Commission on Terrorist Acts Upon the United States.

American Embassy in Brasilia. 2008. Counterterrorism in Brazil: Looking Beyond the Tri-Border Area. Cable 08BRASILIA43. Brasília: American Embassy in Brasilia. .2009a. Brazil: 2009 Country Report on Terrorism. Cable 09BRASILIA1540. Brasília: American Embassy in Brasilia. 2009b. Brazil: Police publicly admit Al Qaeda's presence. Cable 09BRASILIA1206. Brasília: American Embassy in Brasilia.

Brasil. Supremo Tribunal Federal. 2005. Extradição 855, Relator Min. CELSO DE MELLO, Tribunal Pleno, julgado em 26 ago 2004, DJ 01-07-2005 PP-00005 EMENT VOL-02198-1 PP-00029 RB v. 17, n. 501.

Brasil. Câmara dos Deputados. 2009. Debate sobre a atuação de membros de grupos terroristas no território brasileiro. Comissão de Segurança Pública e Combate ao Crime Organizado. Brasília: Câmara dos Deputados.

Comitê Olímpico Internacional. s.d. Relatório da Comissão de Avaliação. 
FATF; GAFISUD. 2010. Mutual Evaluation Report: Anti-money laundering and combating the financing of terrorism Federative Republic of Brazil. Paris: Financial Action Task Force.

IEP. 2012. Global Terrorism Index: Capturing the impact of terrorism from 2002-2011. New York: Institute for Economics \& Peace.

2014. Global Terrorism Index 2014. New York: Institute for Economics \& Peace.

OAG. 2006. Office of Criminal Investigations: AMIA Case. Request for Arrests. Office of Criminal Investigations.

United States. Department of State. 2010. Country Reports on Terrorism 2009. Washington, D.C.: US Department of State. 2014. Country Reports on Terrorism 2013. Washington, D.C.: US Department of State.

UNODOC. 2009. Handbook on Criminal Justice Responses to Terrorism. Vienna: United Nations Office on Drugs and Crime. USNCoTAuUS. 2005. Monograph on Terrorism Financing: Staff Report to the Commission. Washington, D.C.: National Commission on Terrorist Attacks Upon the United States.

\begin{abstract}
This article begins by first tracing how international terrorism in the post-9/11 period has impacted Brazil before moving on to diagnose and analyze the legal and institutional design of the Brazilian anti- terrorism structure while also outlining and understanding its key limitations. In order to do so, I rely primarily upon interviews with members of the Brazilian government, including both the Military and Federal Police. I also use declassified and open source documents as well as the relevant legislation on the subject. Focusing on international terrorism after nine eleven, I observed that the problem of international terrorism also occurs within Brazil and map the structure and design of the current anti-terrorism apparatus in the country while also identifying some of its limitations. I then analyze some of the more serious shortcomings of the current Brazilian regulatory system as regards the issue of combating terrorism. Having formulated this understanding of the design of the existing legal and institutional framework on the subject, I conclude that the current legislative drafts being debated in the Brazilian Congress do not respond to the real needs of the country when it comes to the prevention and mitigation of international terrorism and terrorist attacks. These failures reflect both the absence of a strategy as well as specific legislation to fight and prevent terrorism in Brazil. In order to rectify this problem I argue that it is essential to design comprehensive legislation that falls clearly within the framework of criminal justice and which not only incorporates the basic principles of due process and democracy but is also aligned with human rights and humanitarian law. Both these principles and legal branches are best prepared to address the complex cases associated with international terrorism and cannot - and indeed, should not be - in any manner seen as a barrier to countering terrorism in Brazil.
\end{abstract}

KEYWORDS: Brazil; terrorism; political violence; counter-terrorism; legislation.

License information: This is an open-access article distributed under the terms of the Creative Commons Attribution License, which permits unrestricted use, distribution, and reproduction in any medium, provided the original work is properly cited. 